\title{
Molecular Recognition with C-Clamp Porphyrins: Synthesis, Structural, and Complexation Studies
}

\author{
Ying Liang, C. K. Chang* \\ Department of Chemistry, Michigan State University, East Lansing, MI 48824, USA \\ Shie-Ming Peng \\ Department of Chemistry, National Taiwan University, Taipei, Taiwan
}

\begin{abstract}
Porphyrin-based molecular clefts equipped with a strategically positioned carboxylic group have been synthesized. These ditopic porphyrins exhibit excellent binding affinity for many neutral substrates. X-ray structures of a porphyrin-water inclusion complex and a $\mathrm{Zn}$ (porphyrin)-methanol complex reveal how the carboxylic group interacts with substrates via H-bonding. Multipoint recognition is demonstrated in the differential binding of $1,2,3$ - versus $1,2,4$-triazole, suggesting the possible use of such receptors to separate heterocyclic bases.
\end{abstract}

Keywords: Porphyrin; Kemp's triacid; H-bonding; substrate binding; imidazole; purine; 1,2,3-triazole, 1,2,4-triazole

\section{Introduction}

Molecular recognition plays an important role in biological systems. Highly specific interactions between proteins and ligands provide the basis for protein function. There have been extensive studies focusing on the design and synthesis of biomimetic host-guest systems that may provide insights to biological processes (Schneider and Durr, 1991). In the efforts at mimicking heme proteins, numerous model porphyrins have been synthesized for studies of mainly metal-centered interactions such as dioxygen binding (Momenteau and Reed, 1994). The porphyrin macrocycle, despite the crucial biological functions of its metal derivatives, usually does not have enough functionalized binding sites to interact with substrates. However, the porphyrin ring can be easily linked to other functional groups at the peripheral meso and $\beta$-pyrrole positions. Recent advances in the synthesis of functionalized prophyrins have made it possible to develop porphyrin-based receptors with a variety of sizes, shapes and functional surfaces. The relatively rigid and disk-shaped porphyrins are suitable to serve as a framework in building molecular clefts that function independently of the porphyrin. The presence of NH protons or metal ions at the porphyrin center can provide additional binding sites to aid the complexation of guest molecules. This flexibility in design and synthesis makes modified porphyrins useful not only in mimicking their biochemical functions, but also in developing new types of receptors for artificial molecular recognitions. The mechanism which allows the binding of specific ligands can be ascribed to hydrogen bonding, $\pi \pi$ stacking and metalligand coordination. Various porphyrin receptors have been designed for recognizing amino acids, nucleobase pairs, barbiturates and polyols (Bonar-Law and Sanders, 1995; Imai et al., 1992; Kuroda and Ogoshi, 1994; Lindsey et al., 1988; Mizutani et al., 1994; Slobodkin et al., 1992).

- Author to whom correspondence should be addressed
We wish to report here the study of a novel C-clamp shaped molecular receptor in which a porphyrin ring is supplemented by a carboxylic acid group pointing towards the porphyrin center. This acid functional group combined with the pyrrole NH or metal ion of the porphyrin furnishes a ditopic binding site capable of specific substrate recognition. As shown in Fig. 1, the acid functionality is linked to the porphyrin ring via two perpendicular spacers. Spacer $I$ is a rigid aromatic moiety attached to porphyrin meso-position and flanked by two methyl groups to limit its freedom of rotation. Spacer II is conveniently part of the Kemp's triacid whose utility as a converging building block for molecular receptors has been well demonstrated by Rebek (Rebek, 1987, 1990). The combination of the Kemp's triacid and naphthalene or an anthracene connector thus gives us a Cshaped receptor with a relatively rigid acid hovering over the porphyrin. The C-clamp porphyrins have been used to enhance $\mathrm{O}_{2}$ binding to the Co(II) porphyrin (Chang et al., 1995), and to form inclusion complexes with small neutral guests (Liang and Chang, 1995). We report here details of the synthesis, structures and molecular interactions with a number of substrates.

\section{Synthesis}

The synthesis of the naphthalene Kemp's acid porphyrin (NKAP) and the anthracene Kemp's acid porphyrin

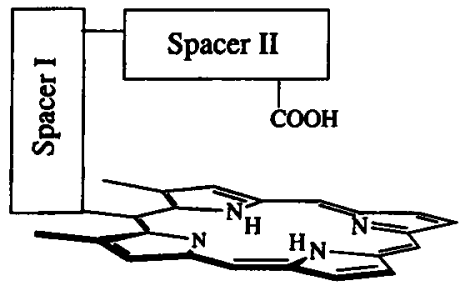

Figure 1. Essential components of the C-clamp porphyrin. 


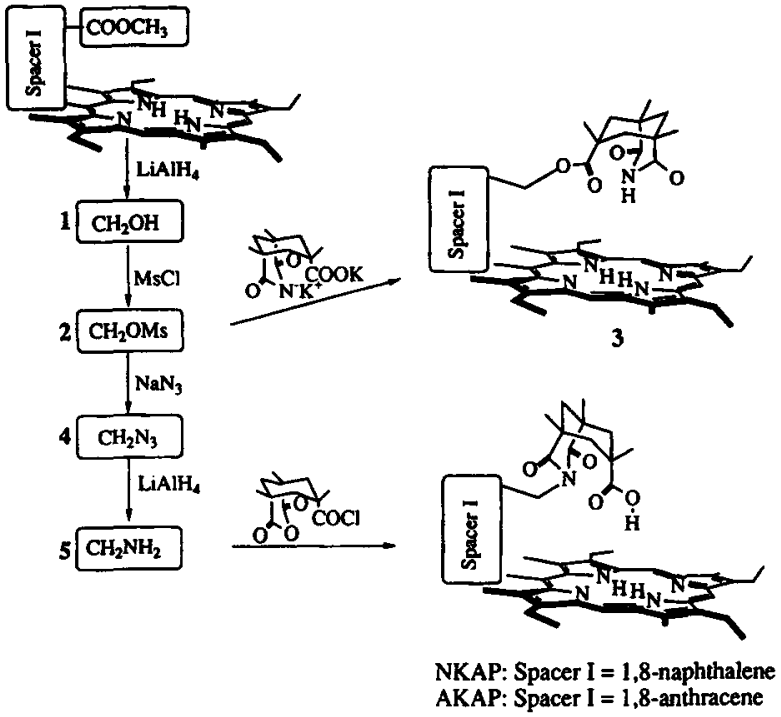

Figure 2. General synthetic scheme.

(AKAP) are outlined in Fig. 2. For NKAP, the starting ester prophyrin (Chang and Kondylis, 1986) was converted into its zinc complex before being reduced by $\mathrm{LiAlH}_{4}$ in dry THF, since direct reduction sometimes gave aluminuminserted porphyrin which is nearly impossible to demetalate. The resulting alcohol was treated with excess (10 equiv.) methanesulfonyl chloride at room temperature without heating to minimize decomposition. The excess reagent was removed by vacuum pump. Reaction of this mesylate with the potassium imide-carboxylate salt did not give the NKAP, but instead an isomer. With the anthracene homologue, the same reaction also occurred to yield an isomer. The first evidence of isomer formation came from the failure in transforming it into an ester by diazomethane, as well as the inability to lose $\mathrm{CO}_{2}$ in the mass spectrum, as expected for carboxylic acid compounds. Clearly, the less nucleophilic, but more exposed carboxylate was more reactive than the imide towards the highly hindered mesylate carbon. Hence, an alternative synthetic pathway was designed.

Rebek has reported the condensation of various amines with the acid chloride-anhydride (Rebek et al., 1985). Therefore, we decided to choose this route and prepared an amine for coupling (Fig. 2). The mesylate reacted with excess sodium azide in DMF to give the azido-porphyrin in 99\% yield. IR spectrum of this porphyrin showed a strong azide absorption band at $2096 \mathrm{~cm}^{-1}$. After reducing the zinc azido-porphyrin by $\mathrm{LiAlH}_{4}$, the amino porphyrin was coupled with the acid chloride-anhydride to successfully generate NKAP. The overall yield was $60 \%$ for NKAP. The anthracene homologue was prepared similarly with a slightly better yield (72\%). 'H NMR of NKAP and AKAP showed that the capping cyclohexyl protons have substantial upfield shift (Fig. 3). The gem-methyl group to the $\mathrm{CO}_{2} \mathrm{H}$ was found at $-0.26 \mathrm{ppm}$ in NKAP and $0.37 \mathrm{ppm}$ in AKAP compared to $1.40 \mathrm{ppm}$ in the starting Kemp's acid chloride-anhydride, which is obviously due to the diamagnetic ring current.

In the 'H NMR studies of NKAP, the typical NH proton signals in the -3 to $-4 \mathrm{ppm}$ region were not detected at room temperature; instead a broad peak around $0 \mathrm{ppm}$ was observed (Fig. 3). This phenomenon suggests proton exchange among the $\mathrm{NH}$ protons of the porphyrin and the carboxylic acid proton. When the acid group was methylated by $\mathrm{CH}_{2} \mathrm{~N}_{2}$, the $\mathrm{NH}$ protons emerged at $-3.2 \mathrm{ppm}$ as a doublet. Similar behavior for AKAP was observed. Here, intermolecular proton exchange is not probable since the Cshaped geometry obstructs close contact of the acid proton to another porphyrins NH protons. In order to probe this intramolecular exchange, variant temperature NMR (Sandström, 1982; Õki, 1985) was employed to monitor the dynamics of the proton exchange at $500 \mathrm{MHz}$ in these two systems. For NKAP, a sharp peak around $-4 \mathrm{ppm}$ at

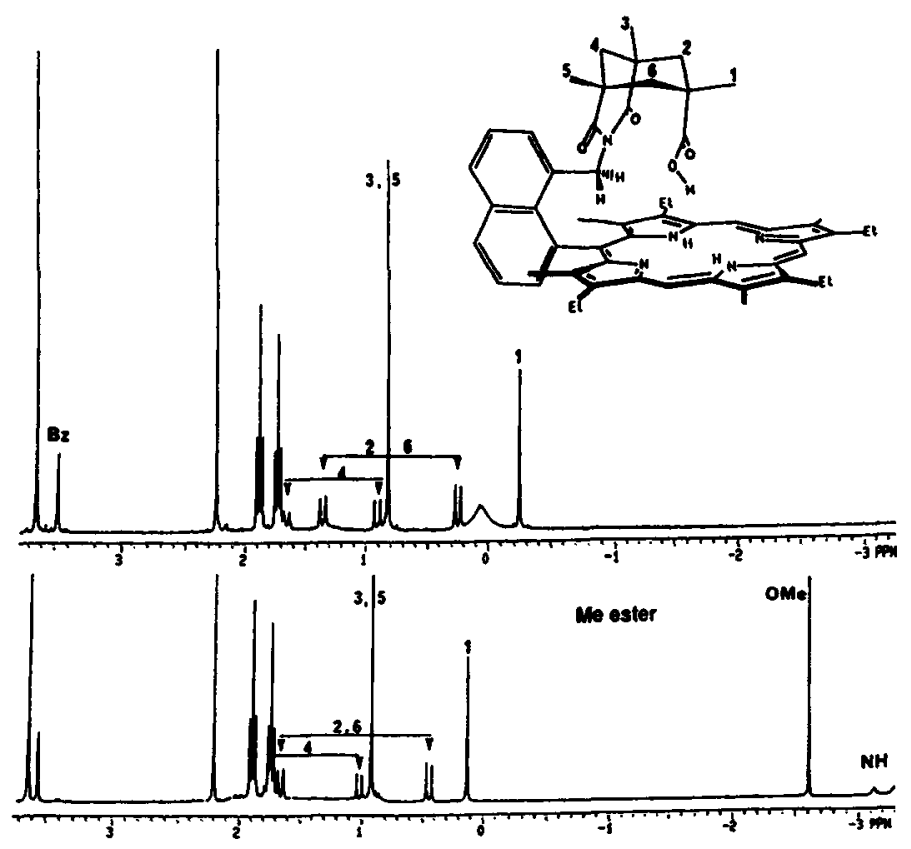

Figure 3. 'H NMR of NKAP and the methyl ester derivative. 
$-90^{\circ} \mathrm{C}$ was observed, which gradually broadened out. When temperature reached $20^{\circ} \mathrm{C}$, a new signal centered at $0 \mathrm{ppm}$ appeared as the averaged signal of the porphyrin $\mathrm{NH}$ protons and the acid proton. Over the entire temperature range accessible in $\mathrm{CD}_{2} \mathrm{Cl}_{2}\left(-90\right.$ to $\left.40^{\circ} \mathrm{C}\right)$, the signal of the carboxylic acid proton was not obvious, possibly due to overlapping with other signals, and this acid proton was identified at $3.6 \mathrm{ppm}$ by saturation spin transfer techniques (Dahlquist et al. 1975) under conditions of slow exchange. The coalescence temperature detected for NKAP was $-10^{\circ} \mathrm{C}$ and for AKAP $15^{\circ} \mathrm{C}$. This agrees well with the expectation that in NKAP the acid proton is closer to the porphyrin center and less energy is needed for the coalescence to occur. Even though coalescence temperature may change due to changes in chemical shift for the two sites, this is not the major determining factor for NKAP and AKAP, since the difference in chemical shift of the two exchanging sites of these systems is quite small.

\section{Crystal Structure}

The crystal structure of NKAP- $\mathrm{H}_{2} \mathrm{O}$ inclusion complex has been published previously (Chang et al., 1995) and the structure of $\mathrm{ZnNKAP}-\mathrm{MeOH}$ is shown in Fig. 4. The selected bond distances and angles of ZnNKAP are given in Table 1.

The zinc complex of NKAP crystallized from methylene chloride solution layered with methanol has a methanol molecule as axial ligand with the $\mathrm{O}-\mathrm{Zn}$ distance of $2.1587(24) \AA$. The methanolic proton is H-bonded to the carbonyl group of the Kemp's acid with a distance of $1.98(3) \AA$. In order to accommodate this $\mathrm{H}$ bond, the superstructure is twisted off center (Fig. 4b). The naphthalene spacer and the porphyrin ring also distort severely from the ideal $\mathrm{C} 20-\mathrm{C} 33$ axis (Fig. 4c). The 'jaw-opening' observed in ZnNKAP is even greater than that in the free base NKAP. In both structures, the porphyrin skeleton remains essentially unchanged. The $\mathrm{X}$-ray structures clearly indicate that the NKAP system is ideal for binding small, preferably monoatomic substrates. By inference supported by molecular modeling, the AKAP compounds with a greater porphyrin to acid distance should serve as good receptors for larger substrates.

\section{Substrate Binding of Metal-free Systems}

The magnitude of molecular inclusion was followed by ${ }^{\prime} \mathrm{H}$ NMR titration carried out in $\mathrm{CDCl}_{3}$. Upon stepwise addition of guest molecules into the porphyrin solution, all the protons of the Kemp's acid superstructure exhibited downfield shift due to less diamagnetic ring current. This downfield shift suggested that upon binding of the guest molecule, a 'jaw-opening' motion occurred at the porphyrin-spacer I conjunction. On the other hand, along this motion, the naphthyl porton on C34 experienced an upfield shift due to the tilting of naphthalene, bringing this proton closer to the porphyrin. A similar shift was also observed for the corresponding proton on anthracene in AKAP. The binding constants were derived from the chemical shift of naphthyl or anthryl methylene protons as well as by distinctive shifts of other protons during the titration process.

For studying the $\mathrm{H}_{2} \mathrm{O}$ binding to NKAP, it is crucial that all reagents and the NMR tube are as anhydrous as possible. The binding of water of NKAP is strong enough that the saturation point can be reached before the solubility of water in $\mathrm{CDCl}_{3}$ becomes a problem (Staverman, 1941). Fig. 5(a) displays ' $H$ NMR spectra showing the chemical shift of the naphthyl methylene proton at varying concentrations of water. For the AKAP binding of imidazole or purine, the interaction presumably relies on multipoint recognition as depicted by the computer model (Fig. 6). The titration data give a 1:1 complex with binding constants of 2550 and $2600 \mathrm{M}^{-1}$ for imidazole and purine, respectively. As purine is a weaker base than imidazole (Table 2), the comparable binding strength of the two bases suggests that the intrinsic basicity is not the determining binding force. In our systems, $\pi-\pi$ interactions between the guest and host molecules need not to be considered. Therefore, the attractive forces come solely from the $\mathrm{H}$-bonding network.

The DSC (differential scanning calorimetry) analysis was also appplied to the solid crystals of NKAP- $\mathrm{H}_{2} \mathrm{O}$. The DSC showed two endothermic peaks, with the first one attributable to dehydration and the second peak coinciding with the melting of the compound. Continuous heating led to decomposition. The heat flow associated with the first peak is $17.58 \mathrm{~J} \mathrm{~g}^{-1}$, indicating that the water binding energy is about $-15 \pm 1 \mathrm{~kJ} \mathrm{~mol}^{-1}$ (Liang and Chang, 1995).

\section{Substrate Binding of Zinc Porphyrins}

To estimate how much stabilization energy the C-clamp acid group can impart to metalloporphyrin-ligand binding, we examined the zinc porphyrin as a model. The same protocol of ' $\mathrm{H}$ NMR titration as mentioned previously was used for the C-clamp zinc porphyrin systems. A typical NMR titration of ZnNKAP-MeOH is shown in Fig. 5(b). For the control study using $\mathrm{ZnOEP}$ (octaethylporphyrin), whose guest-host interactions cannot be easily followed by 'H NMR, UV-vis spectroscopy was used to monitor ligand binding. The binding constants of these systems are listed in Table 2.

Methanol ligation to zinc porphyrin is well studied (Bonar-Law and Sanders, 1995). ZnNKAP binds MeOH more strongly than the unfunctionalized ZnOEP $\left(\Delta \Delta G=3.1 \mathrm{~kJ} \mathrm{~mol}^{-1}\right)$ due to the additional binding force derived from the H-bonding clearly shown in the crystal structure.

The most dramatic effect in molecular inclusion is seen in the case of triazoles. 1,2,4-Triazole, being a weaker base $\left(\mathrm{p} K_{\mathrm{a}} 2.3\right)$ (Albert, 1968) than imidazole, is normally not a strong ligand for metalloporphyrins. But ZnAKAP maximizes the binding by a three-point contact as depicted in the schematic structure (Fig. 7). The binding constant is $21000 \pm 1000 \mathrm{M}^{-1}$, with a free energy gain of $9.9 \mathrm{~kJ} \mathrm{~mol}^{-1}$. ${ }^{1} \mathrm{H}-1,2,3-t r i a z o l e$, capable of only a two-point interaction, displays a significant decrease in binding energy $\left(\Delta \Delta G 4.8 \mathrm{~kJ} \mathrm{~mol}^{-1}\right)$. The binding of 1,2,4-triazole was conducted by adding aliquots of concentrated $\mathrm{CD}_{3} \mathrm{OD}$ 
solution of the base to the zinc porphyrin dissolved in $\mathrm{CDCl}_{3}$ due to insolubility of the base in pure $\mathrm{CDCl}_{3}$. The 1,2,3-triazole study was measured in pure $\mathrm{CDCl}_{3}$, as well as by the mixed solvent method. Both methods gave essentially the same binding constant within the margin of experimental error. Therefore, it is safe to assume that methanol cannot compete effectively with 1,2,4-triazole in binding with the host molecule, and the presence of small amounts $(<5 \%)$ of methanol does not distort the binding constant.

\section{Discussion}

The X-ray structure of the NKAP- $\mathrm{H}_{2} \mathrm{O}$ complex allows a rare opportunity to examine the geometries of the acid- $\mathrm{H}_{2} \mathrm{O}$ interface. Ab initio calculations of benzoic acid monohydrate predict two possible conformations, syn and anti, with the syn being the more stable form (Nagy et al., 1994). The optimized geometric distances and angles are shown in Fig. 8. The salient feature is that the $\mathrm{H}$-bond $\mathrm{COH} \cdots \mathrm{O}$ is slightly shorter and less bent than the $\mathrm{C}=\mathrm{O} \cdots \mathrm{H}$ bond. Our

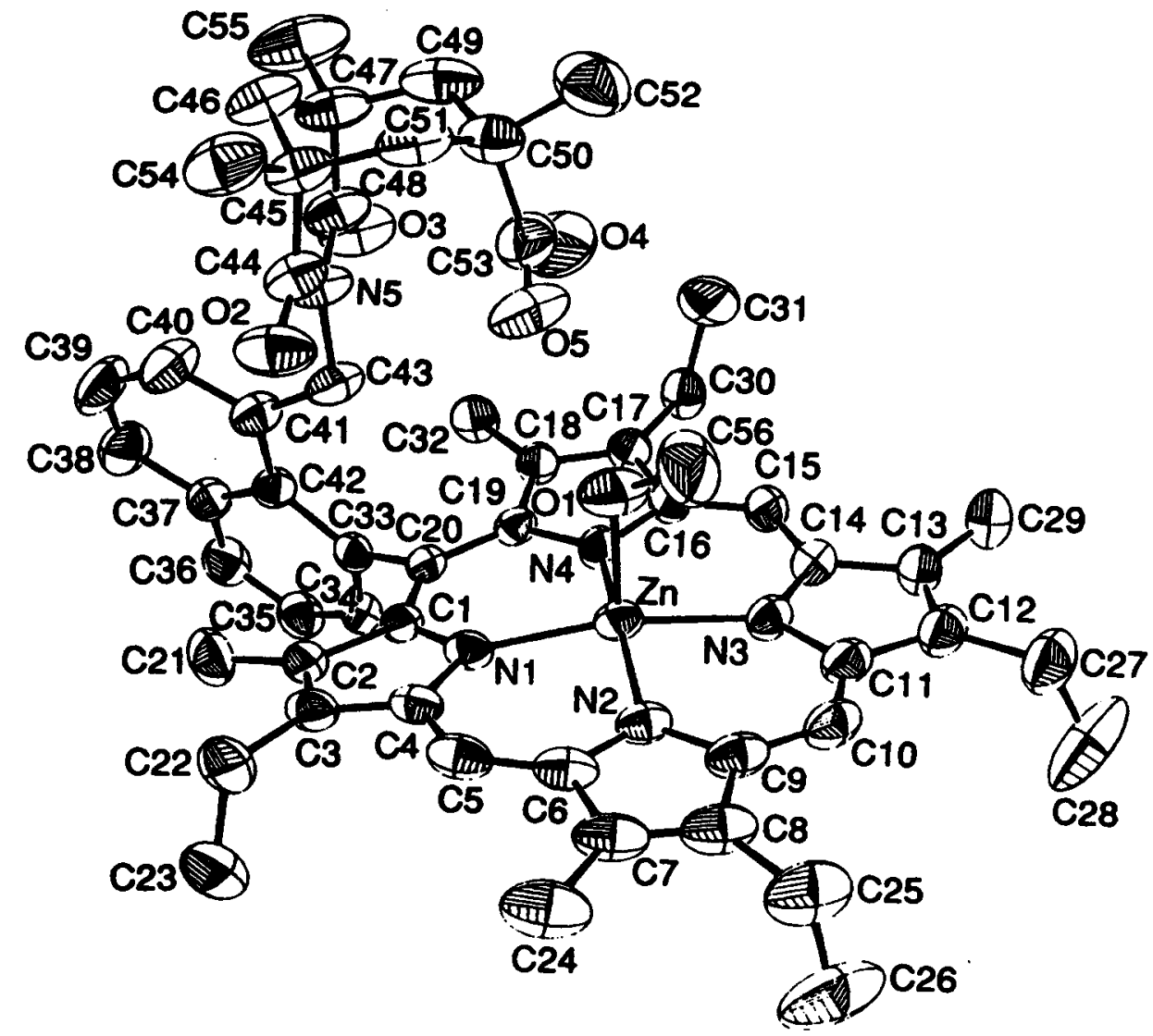

(B)

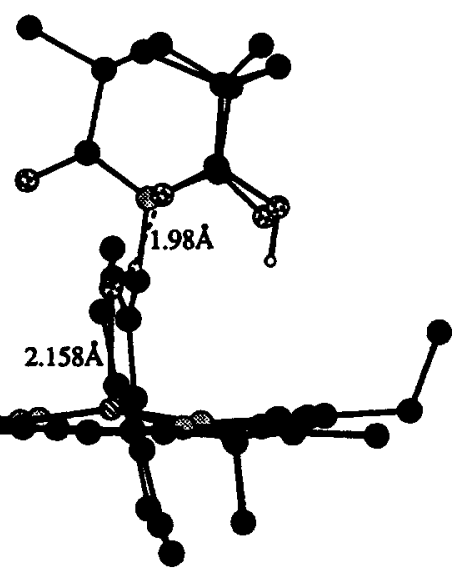

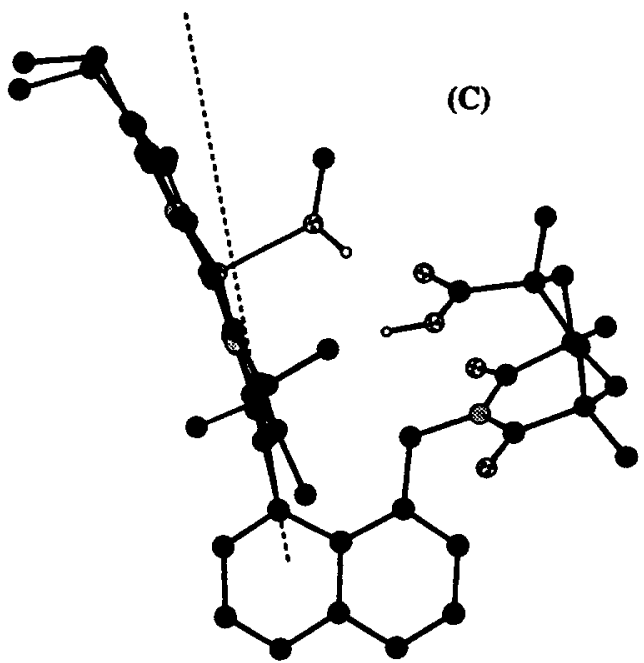

Figure 4. (a) X-ray crystal structure of ZnNKAP-MeOH. (b) Side view of the X-ray structure of ZnNKAP$\mathrm{MeOH}$. (c) Side view from another angle showing the porphyrin outward bending. 
NKAP- $\mathrm{H}_{2} \mathrm{O}$ clearly displays a syn conformation with a slightly shorter and near-linear $\mathrm{COH} \cdots \mathrm{O}$ and a more bent $\mathrm{H}$ bonding for the carbonyl group. The agreement between our structure and the theoretical model seems excellent given the other constraints that the water has to meet within this artificial molecular cleft.

The molecular inclusion of C-clamp porphyrins is brought about by multiple H-bonding. It is always interesting to identify the contribution of each individual hydrogen bond within the overall free energy of complexation. Selective removal of certain H-bonding participants from either the receptor or the substrate has been an important tactic in addressing this question. However, $\mathrm{H}$ bond obliteration studies of this type must be treated with caution since other changes in the molecular properties, such as basicity and conformation, may contribute to the differences in binding energy. A comparison of ZnOEP vs ZnAKAP binding of ' $\mathrm{H}-1,2,3$-triazole provides an estimation of the magnitude of $\mathrm{H}$ bonding strength of acid $\mathrm{C}=\mathrm{O} \cdots \mathrm{H}$. The energy difference here is $7.8 \mathrm{~kJ} \mathrm{~mol}^{-1}$. This $\Delta \Delta G$ may be compared to the $3.1 \mathrm{~kJ} \mathrm{~mol}^{-1}$ observed in $\mathrm{MeOH}$ binding to $\mathrm{ZnNKAP}$ vs $\mathrm{ZnOEP}$. The difference clearly has something to do with the acidity of the proton (NH vs $\mathrm{OH}$ ). Another useful comparison is the 3-point (1,2,4-triazole) vs 2 -point ( ${ }^{1} \mathrm{H}-1,2,3$-triazole) contact. The $\Delta \Delta G$ value of $4.8 \mathrm{~kJ} \mathrm{~mol}^{-1}$ arises from more than just the extra $\mathrm{H}$-bond. The basicity difference of the two triazoles has significantly influenced the $\mathrm{Zn}-\mathrm{N}$ bond $\left(2.7 \mathrm{~kJ} \mathrm{~mol}^{-1}\right)$ whereas its effect on the $\mathrm{NH} \cdots \mathrm{O}=\mathrm{C}$ is possibly very small.

In conclusion, our functionalized porphyrin receptors, NKAP, AKAP and their zinc complexes, are capable of binding and recognizing various small neutral molecules. The shape and rigidity of superstructure porphyrin make possible some very effective complexation of substrates through multipoint recognition. The selectivity demonstrated by ZnAKAP suggests possible applications for the separation of heterocyclic bases. It is also possible to further modify the overhanging carboxyl group to effect more sophisticated substrate binding and recognition.

\section{Experimental Section}

\section{Materials and measurements}

Reagents and solvents for synthesis were used as received unless otherwise stated. $\mathrm{CH}_{2} \mathrm{Cl}_{2}$ and DMF were distilled from $\mathrm{CaH}_{2}$. THF and toluene were freshly distilled from

Table 1. Selected bond distances $(\AA)$ and angles (deg) and their estimated standard deviations for ZnNKAP

\begin{tabular}{llll} 
& \multicolumn{1}{c}{ Distance (A) } & & \multicolumn{1}{c}{ Angles (deg) } \\
Zn-N1 & $2.0482(24)$ & N1-Zn-N2 & $91.36(10)$ \\
Zn-N2 & $2.063(3)$ & N1-Zn-N4 & $87.45(9)$ \\
Zn-N3 & $2.063(3)$ & N2-Zn-N3 & $87.44(10)$ \\
Zn-N4 & $2.0578(24)$ & N3-Zn-N4 & $90.63(9)$ \\
Zn-O & $2.1587(24)$ & C20-C33-C42 & $126.0(3)$ \\
O(5)-HO(1) & $1.98(3)$ & C42-C41-C43 & $120.8(3)$ \\
$O(1)-H O(1)$ & $0.76(3)$ & $O(1)-H O(1)-O(5)$ & $159(4)$ \\
\hline
\end{tabular}

$\mathrm{LiAlH}_{4}$. UV-visible spectra were measured on a Cary 219 or a Shimadzu 160 spectrophotometer. 'H NMR spectra were recorded on Varian Gemini-300 in ' $100 \%$ ' $\mathrm{CDCl}_{3}$ (minimum 99.8 atom \% D, Cambridge Isotope Laboratories) with the residue $\mathrm{CHCl}_{3}$ as the internal standard set at $7.24 \mathrm{ppm}$. Variant temperature NMR measurements were conducted on a Varian $500 \mathrm{MHz}$ NMR spectrometer. Mass spectra were measured from a benchtop VG Trio-1 mass spectrometer or FAB (fast atom bombardment) on a JEOL HX-110 HF double focusing spectrometer in the positive ion detection mode. Infrared spectra were obtained from sample film on an $\mathrm{NaCl}$ plate and recorded on a Nicolet IR 42 spectrometer.

5-[8-(Hydroxymethyl)-1-naphthyl]-2,8,13,17-tetraethyl-3,7,12, 18-tetramethylporphyrin (1). To 5-(8-methoxycarbonyl-1naphthyl)2,8,13,17 - tetraethyl - 3,7,12,18 - tetramethylpor phyrin (Chang and Kondylis, 1986) (2.1 g, $3.17 \mathrm{mmol}$ ) dissolved in methylene chloride $(400 \mathrm{ml})$ was added a saturated methanolic solution of zinc acetate containing sodium acetate. The mixture was heated to reflux for 10 minutes before washing with water $(50 \mathrm{ml})$, dried over $\mathrm{Na}_{2} \mathrm{SO}_{4}$ and evaporated to dryness to give the zinc porphyrin. To this material dissolved in freshly distilled THF $(300 \mathrm{ml})$, a suspension of lithium aluminum hydride $(\mathrm{LiAlH}, 0.5 \mathrm{~g})$ in THF was added slowly. The reaction solution was stirred at room temperature for another hour. Completion of the reaction was monitored on TLC by the disappearance of the fast moving starting material. After the reduction was complete, the mixture was quenched by addition of ice water and the product was isolated by extraction with $\mathrm{CH}_{2} \mathrm{Cl}_{2}$ from water. The crude product was purified by column chromatography over silica gel using $2 \% \mathrm{MeOH} / \mathrm{CH}_{2} \mathrm{Cl}_{2}$. The purified zinc porphyrin was redissolved in methylene chloride $(200 \mathrm{ml})$, and demetalated by washing with $10 \% \mathrm{HCl}(200 \mathrm{ml})$. The organic solution was then washed with saturated $\mathrm{NaHCO}_{3}$ and water and dried over anhydrous $\mathrm{Na}_{2} \mathrm{SO}_{4}$. Evaporation afforded $1.63 \mathrm{~g}(81 \%)$ purple crystal of 1 . 'H NMR (300 MHz, $\left.\mathrm{CDCl}_{3}\right) \delta \mathrm{ppm}-3.09(2 \mathrm{H}, \mathrm{d}, \mathrm{NH}), 0.20(1 \mathrm{H}, \mathrm{t}, \mathrm{OH}), 1.71$ $(6 \mathrm{H}, \mathrm{t}, \mathrm{Et}), 1.88(6 \mathrm{H}, \mathrm{t} \mathrm{Et}), 2.13(6 \mathrm{H}, \mathrm{s}, \mathrm{Me}), 3.08(2 \mathrm{H}, \mathrm{d}$, $\left.\mathrm{CH}_{2} \mathrm{O}-\right), 3.65(6 \mathrm{H}, \mathrm{s}, \mathrm{Me}), 3.96(4 \mathrm{H}, \mathrm{m}, \mathrm{Et}), 4.08(4 \mathrm{H}, \mathrm{q}$, $\mathrm{Et}), 9.97$ (1H, s, meso), 10.17 (2H, s, meso), naphthyl: 7.61 $(1 \mathrm{H}, \mathrm{s}), 7.63(1 \mathrm{H}, \mathrm{d}), 7.78(1 \mathrm{H}, \mathrm{t}), 8.01(1 \mathrm{H}, \mathrm{d}) ; 8.17(1 \mathrm{H}$, t), $8.35(1 \mathrm{H}, \mathrm{d}) ; \mathrm{MS}, \mathrm{m} / \mathrm{e}$ (relative intensity) $634\left(\mathrm{M}^{+}\right.$, 86.89); UV-vis $\lambda_{\max } \mathrm{nm}(\varepsilon \mathrm{M}) 625$ (2100), 572 (6400), 538 (6500), 503 (15000), 405 (190000).

5- [8 - (Methanesulfonylmethyl) - 1 - naphthyl] - 2,8,13,17 - tetra ethyl-3,7,12,18-tetramethylporphyrin (2). The above alcohol $1(100 \mathrm{mg}, 0.16 \mathrm{mmol}$ ) was dissolved in $5 \mathrm{ml}$ dry methylene chloride plus 3 drops of trimethylamine. To this mixture stirred under argon in an ice bath, methanesulfonyl chloride $(2 \mathrm{ml})$ was slowly added. The system was continuously stirred for 14 hours at room temperature. The solvent and excess methanesulfonyl chloride was pumped away by a vacuum pump (room temperature until almost dry, then at $60^{\circ} \mathrm{C}$ for 2 hours). This product 2 was used for the next step without further purification.

Naphthalene Kemp's acid isomer porphyrin (3). To the above porphyrin mesylate ( $15 \mathrm{mg}, 0.024 \mathrm{mmol}$ ), the Kemp's imide 

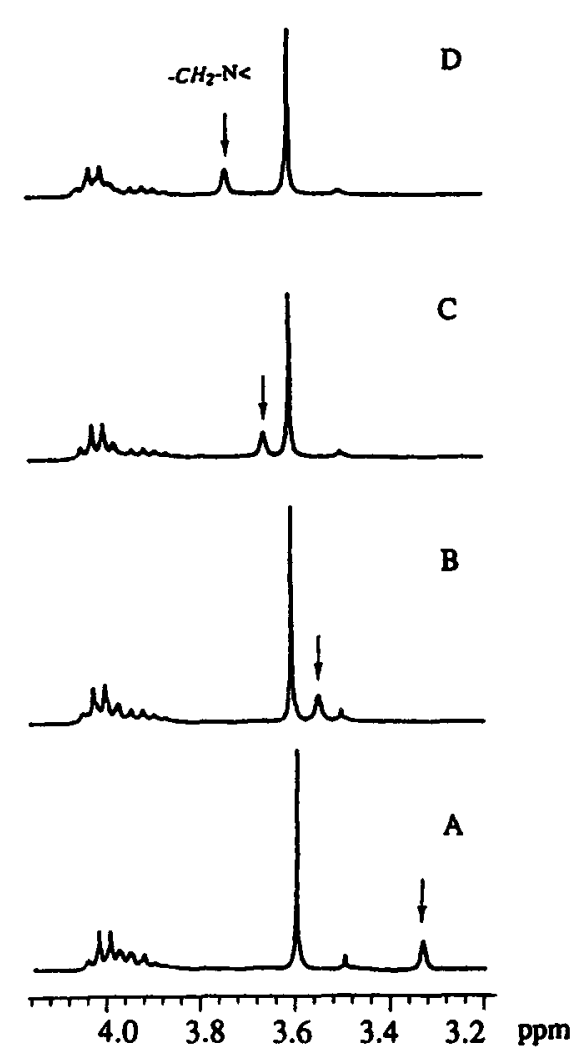

(a)

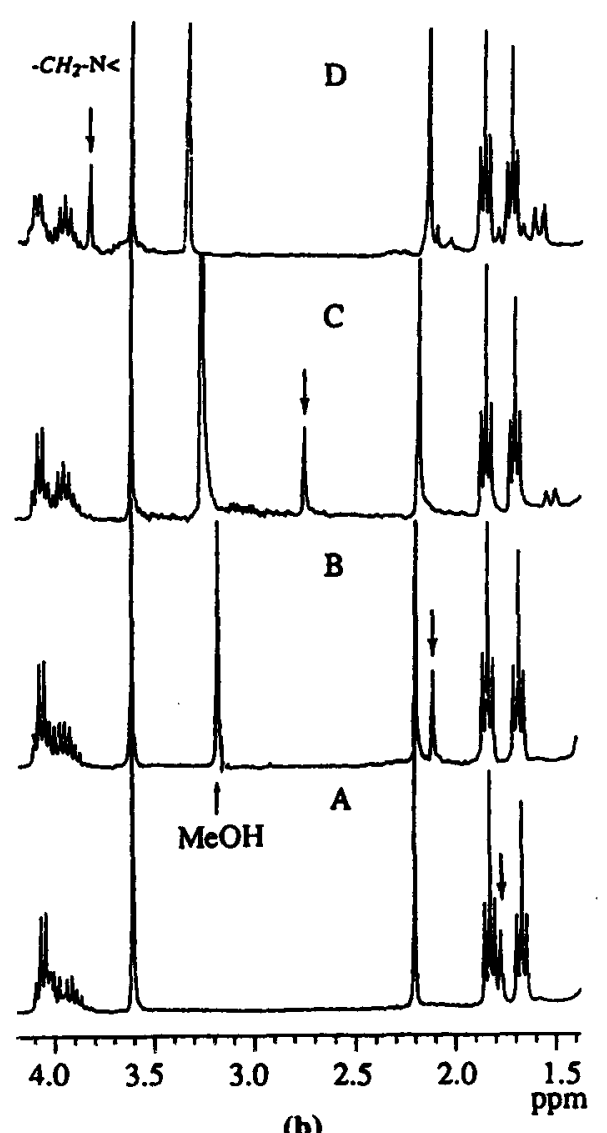

(b)

Figure 5. (a) ' $\mathrm{H}$ NMR titration of water to NKAP. [NKAP] $=3 \mathrm{~mm},\left[\mathrm{H}_{2} \mathrm{O}\right]$ in $\mathrm{A}: 0.000 \mathrm{M} ; \mathrm{B}: 0.022 \mathrm{M}$; C:0.037 M; D:0.047 M. (b) ${ }^{1} \mathrm{H}$ NMR titration of MeOH to ZnNKAP. [ZnNKAP] $=0.014 \mathrm{M}$, [MeOH] in A:0.000 M; B:0.013 M; C:0.066 M; D:0.500 M.

potassium carboxylate $(30 \mathrm{mg}, 0.091 \mathrm{mmol})$ and dry toluene $(20 \mathrm{ml})$ were added. The mixture was refluxed under argon for 12 hours. The excess potassium salt was removed by filtration. After removal of the solvent under vacuum, the product was dissolved in methylene chloride and purified on TLC plate using $1 \% \mathrm{MeOH} / \mathrm{CH}_{2} \mathrm{Cl}_{2}:$ yield, $2.87 \mathrm{mg}, 14 \%$. ${ }^{1} \mathrm{H}$ NMR $\left(300 \mathrm{MHz}, \mathrm{CDCl}_{3}\right) \delta \mathrm{ppm}-3.06(2 \mathrm{H}, \mathrm{d}, \mathrm{NH})$, $1.71(6 \mathrm{H}, \mathrm{t}, \mathrm{Et}), 1.86(6 \mathrm{H}, \mathrm{t}, \mathrm{Et}), 2.12(6 \mathrm{H}, \mathrm{s}, \mathrm{Me}), 3.61(6 \mathrm{H}$, $\mathrm{s}, \mathrm{Me}), 3.86(2 \mathrm{H}, \mathrm{q}, \mathrm{Et}), 3.96\left(2 \mathrm{H}, \mathrm{s},-\mathrm{CH}_{2} \mathrm{~N}<\right), 4.04(6 \mathrm{H}$, $\mathrm{m}, \mathrm{Et}), 9.91(1 \mathrm{H}, \mathrm{s}$, meso $), 10.11(2 \mathrm{H}, \mathrm{s}$, meso), naphthyl: $7.42(1 \mathrm{H}, \mathrm{d}), 7.64(1 \mathrm{H}, \mathrm{t}), 7.71(1 \mathrm{H}, \mathrm{t}), 7.83(1 \mathrm{H}, \mathrm{d}), 8.21$ $(1 \mathrm{H}, \mathrm{d}), 8.31(1 \mathrm{H}, \mathrm{d})$; chair: $-0.60(3 \mathrm{H}, \mathrm{s} \mathrm{Me}), 0.31(1 \mathrm{H}$, d), $0.64(6 \mathrm{H}, \mathrm{s}, \mathrm{Me}), 0.78(1 \mathrm{H}, \mathrm{d}), 1.40(1 \mathrm{H}, \mathrm{d}), 1.63(2 \mathrm{H}$, d), $6.36(1 \mathrm{H}, \mathrm{NH}) ;$ FABMS, m/e (relative intensity) 856 $\mathrm{M}+1,100$ ); UV-vis $\lambda_{\max } \mathrm{nm}$ (relative intensity) 627 (1.0), 574 (8.3), 539 (10.2), 504 (15.5), 409 (219.7).

5 - [8 - (Azidomethyl) - 1 - naphthyl] - 2,8,13,17 - tetraethyl-3,7,12, 18-tetramethylporphyrin (4). The porphyrin mesylate 2 was dissolved in dry DMF $(10 \mathrm{ml})$ and sodium azide $(300 \mathrm{mg})$ was added. The mixture was heated to $90^{\circ} \mathrm{C}$ for 5 hours under argon. After the reaction was done, water was added to the solution and the porphyrin was extracted to the organic layer by methylene chloride. The crude product was

Table 2. Association constants of porphyrins with substrates

$\begin{array}{lcccl}\text { Receptor } & \text { Substrate } & \mathrm{p} K_{0} & K\left(\mathrm{M}^{-1}\right) & \Delta \Delta G\left(\mathrm{~kJ} \mathrm{~mol}^{-1}\right) \\ \text { NKAP } & \mathrm{H}_{2} \mathrm{O} & -1\left(20^{\circ}\right) & 66 \pm 7 & \\ \text { AKAP } & \text { Imidazole } & 7.0 & 2550 \pm 90 & \\ \text { AKAP } & \text { purine } & 2.4 & 2600 \pm 300 & \\ \text { ZnOEP } & \text { MeOH } & -2 & 7 \pm 1 & \\ \text { ZnNKAP } & \text { MeOH } & -2 & 25 \pm 3 & 3.1 \text { (vs ZnOEP) } \\ \text { ZnOEP } & 1,2,3-t r i a z o l e & 1.2 & 130 \pm 20 & \\ \text { ZnAKAP } & 1,2,3-\text { triazole } & 1.2 & 3000 \pm 70 & 7.8 \text { (vs ZnOEP) } \\ \text { ZnOEP } & 1,2,4 \text {-triazole } & 2.3 & 390 \pm 40 & 2.7 \text { (vs 1,2,3-triazole) } \\ \text { ZnAKAP } & 1,2,4 \text {-triazole } & 2.3 & 21000 \pm 1000^{\circ} & 9.9 \text { (vs ZnOEP) } \\ & & & & 4.8 \text { (vs 1,2,3-triazole) }\end{array}$

a The error margin was improved from the early report (Liang and Chang, 1995) using additional data points. 
purified by column chromatography over silica gel using methylene chloride as solvent and crystalized from $\mathrm{CH}_{2} \mathrm{Cl}_{2}$ ' $\mathrm{CH}_{3} \mathrm{OH}$ to give $103 \mathrm{mg}(99 \%)$ of 4 . ' $\mathrm{H}$ NMR (300 $\mathrm{MHz}$,

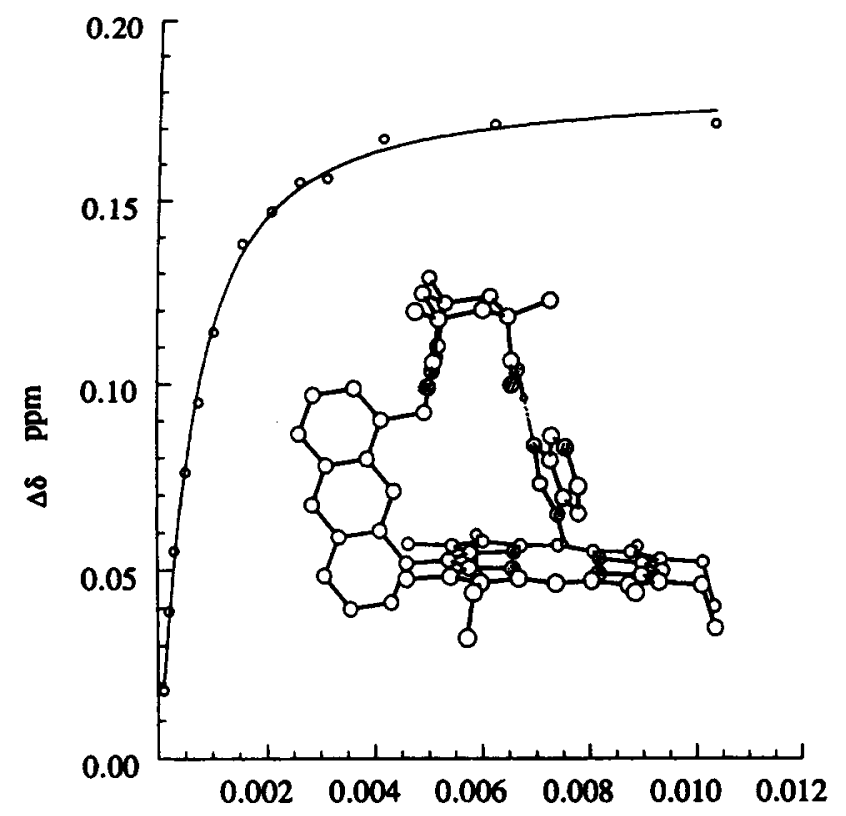

[Purine] $\mathbf{M}$

Figure 6. Schematic structure and curve fitting of AKAP-purine binding.
$\left.\mathrm{CDCl}_{3}\right) \delta \mathrm{ppm}-3.08(2 \mathrm{H}, \mathrm{d}, \mathrm{NH}), 1.73(6 \mathrm{H}, \mathrm{t}, \mathrm{Et}), 1.89$ (6H. t, Et), 2.12 (6H. s, Me), $2.95\left(2 \mathrm{H}, \mathrm{d}, \mathrm{CH}_{2} \mathrm{~N}_{3}\right), 3.66(6 \mathrm{H}$, s, Me). 3.98 (4H, q, Et), 4.10 (4H. q, Et). 9.99 (1H, s, meso), $10.19(2 \mathrm{H}, \mathrm{s}$, meso $)$, naphthyl: $7.49(1 \mathrm{H}, \mathrm{d}), 7.64(1 \mathrm{H}, \mathrm{t})$, $7.80(1 \mathrm{H}, \mathrm{t}), 8.03(1 \mathrm{H}, \mathrm{dd}) ; 8.22(1 \mathrm{H}, \mathrm{d}), 8.36(1 \mathrm{H}, \mathrm{dd})$; FAB-MS, $\mathrm{m} / \mathrm{e}$ (relative intensity) $660(\mathrm{M}+1,3.17)$; UV-vis $\lambda_{\max } \mathrm{nm}(\varepsilon \mathrm{M}) 625(2100), 572(6400), 538(6500), 503$ (15000), 405 (190000); IR: $2096 \mathrm{~cm}^{-1}$ (strong).

5-[8-(Aminomethyl)-1-naphthyl]-2,8.13,17-tetraethyl-3,7,12, 18-tetramethylporphyrin (5). Zinc was inserted into $50 \mathrm{mg}$ of porphyrin 4 using the procedure described previously for the ester porphyrin 1 . To the dried zinc porphyrin dissolved in freshly distilled THF $(15 \mathrm{ml})$, cooled in an ice bath and stirred under argon, a suspension of $\mathrm{LiAlH}_{4}(20 \mathrm{mg})$ in THF was added slowly. The mixture was stirred for another 10 minutes. The reduction was monitored by TLC as the product has a relatively smaller $R_{f}$ value compared to that of the starting material. After the reaction was done, ice water was added cautiously to the reaction flask. The THF was evaporated, and the porphyrin was extracted into methylene chloride and evaporated to dryness. Column chromatography (silica, $\mathrm{CH}_{2} \mathrm{Cl}_{2}$ ) provided the pure zinc amino-porphyrin. The zinc complex was then partitioned in $\mathrm{CH}_{2} \mathrm{Cl}_{2}$ and $10 \% \mathrm{HCl}$, the $\mathrm{CH}_{2} \mathrm{Cl}_{2}$ layer of porphyrin was washed with saturated $\mathrm{NaHCO}_{3}$ and water, and evaporated to give $29 \mathrm{mg}(61 \%)$ of 5 . ' $\mathrm{H}$ NMR $\left(300 \mathrm{MHz}, \mathrm{CDCl}_{3}\right) \delta$ ppm - 3.09(2H, br, NH), $0.89\left(2 \mathrm{H}, \mathrm{t}, \mathrm{NH}_{2}\right), 1.70(6 \mathrm{H}, \mathrm{t}, \mathrm{Et})$, $1.88(6 \mathrm{H}, \mathrm{t}, \mathrm{Et}), 2.12(6 \mathrm{H}, \mathrm{s}, \mathrm{Me}), 2.39\left(2 \mathrm{H}, \mathrm{s}, \mathrm{CH}_{2} \mathrm{~N}\right), 3.65$ $(6 \mathrm{H}, \mathrm{s}, \mathrm{Me}), 3.88(2 \mathrm{H}, \mathrm{q}, \mathrm{Et}), 3.97(2 \mathrm{H}, \mathrm{q} \mathrm{Et}), 4.08(4 \mathrm{H}, \mathrm{q}$, Et), 9.97 (1H, s, meso), 10.16 (2H, s, meso), naphthyl: 7.52

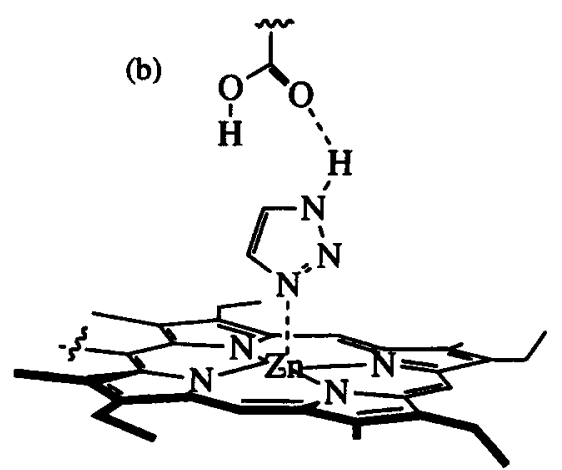

Figure 7. (a) ZnAKAP-1,2,4-triazole. (b) ZnAKAP-1,2,3-triazole.

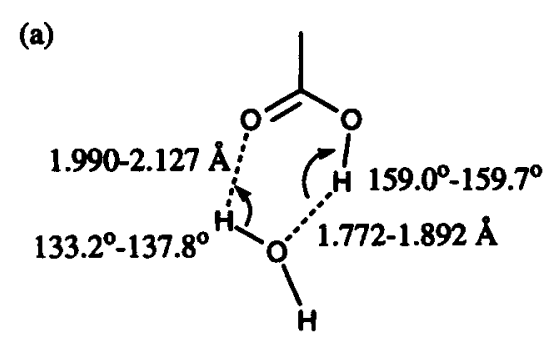

(b)

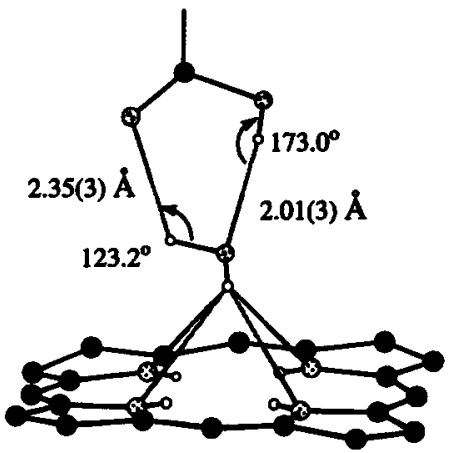

Figure 8. (a) Calculated structure of syn acid monohydrates. (b) Partial X-ray crystal structure of NKAP- $\mathrm{H}_{2} \mathrm{O}$. 
$(1 \mathrm{H}, \mathrm{d}), 7.61(1 \mathrm{H}, \mathrm{t}), 7.77(1 \mathrm{H}, \mathrm{t}), 8.00(1 \mathrm{H}, \mathrm{dd}) ; 8.13(1 \mathrm{H}$, dd), $8.32(1 \mathrm{H}, \mathrm{dd}) ; \mathrm{MS}, \mathrm{m} / \mathrm{e}$ (relative intensity) $633\left(\mathrm{M}^{+}\right.$, 2.56); UV-vis $\lambda_{\max } \mathrm{nm}(\varepsilon \mathrm{M}) 625$ (2100), 572 (6400), 538 (6500), 503 (15000), 405 (190000).

5-(8- (endo - 7 - (Hydroxycarbonyl) - 1,5,7-trimethyl - 2,4-dioxo3-azabicyclo[3,3,1]non - 3-yl] - methyl-1 - naphthyl\} - 2,8,13,17 tetraethyl-3,7,12,18-tetramethylporphyrin (NKAP). The Kemp's imide-acid chloride was prepared as reported previously (Rebek et al., 1985). 5-[8-(Aminomethyl)1-naphthyl]-2,8,13,17-tetraethyl-3,7,12,18-tetramethyl-porphyrin $5(57 \mathrm{mg}, 0.09 \mathrm{mmol})$ was dissolved in freshly distilled toluene $(5 \mathrm{ml})$ and stirred under argon. To this solution, a catalytic amount of dimethylaminopyridine (DMAP) and 2,6-di-t-butylpyridine $(46 \mathrm{mg})$ and Kemp's imide-acid chloride $(28 \mathrm{mg}, 1.0 \mathrm{mmol})$ were added. The mixture was refluxed under argon for 19 hours. The solvent was evaporated and methylene chloride was added. Purification from preparation TLC plate (silica gel, 1\% $\mathrm{CH}_{3} \mathrm{OH} / \mathrm{CH}_{2} \mathrm{Cl}_{2}$ ) and recrystallization from $\mathrm{CH}_{2} \mathrm{Cl}_{2} / \mathrm{CH}_{3} \mathrm{OH}$ gave $77 \mathrm{mg}(75 \%)$ of NKAP. mp: $298{ }^{\circ} \mathrm{C} \mathrm{dec} ;{ }^{1} \mathrm{H}$ NMR $\left(300 \mathrm{MHz}, \mathrm{CDCl}_{3}\right) \delta \mathrm{ppm} 1.73(6 \mathrm{H}, \mathrm{t}, \mathrm{Et}), 1.88(6 \mathrm{H}, \mathrm{t}, \mathrm{Et})$, $2.21(6 \mathrm{H}, \mathrm{s}, \mathrm{Me}), 3.28\left(2 \mathrm{H}, \mathrm{s}, \mathrm{CH}_{2} \mathrm{~N}\right), 3.62(6 \mathrm{H}, \mathrm{s}, \mathrm{Me})$, $3.82-4.08(8 \mathrm{H}, \mathrm{m}, \mathrm{Et}), 9.93(1 \mathrm{H}, \mathrm{s}$, meso $), 10.19(2 \mathrm{H}, \mathrm{s}$, meso), naphthyl: $6.67(1 \mathrm{H}, \mathrm{d}), 7.45(1 \mathrm{H}, \mathrm{t}), 7.69(1 \mathrm{H}, \mathrm{t})$, $7.78(1 \mathrm{H}, \mathrm{dd}) ; 8.04(1 \mathrm{H}, \mathrm{d}), 8.27(1 \mathrm{H}, \mathrm{dd})$, kemp: -0.26 $(3 \mathrm{H}, \mathrm{s}, \mathrm{Me}), 0.23\left(2 \mathrm{H}, \mathrm{d}, \mathrm{CH}_{2}\right), 0.80(6 \mathrm{H}, \mathrm{s}, \mathrm{Me}) 0.88(1 \mathrm{H}$, $\left.\mathrm{d}, \mathrm{CH}_{2}\right), 1.30\left(2 \mathrm{H}, \mathrm{t}, \mathrm{CH}_{2}\right), 1.63\left(1 \mathrm{H}, \mathrm{d}, \mathrm{CH}_{2}\right) ; \mathrm{MS}, \mathrm{m} / \mathrm{e}$ (relative intensity) $855\left(\mathrm{M}^{+}, 7.86\right)$; UV-vis $\lambda_{\max } \mathrm{nm}(\varepsilon \mathrm{M})$ 622 (2000), 570 (6300), 540 (6000), 507 (12000), 406 (140000).

\section{Determination of Binding Constants}

A. NMR method. The receptor molecules NKAP, AKAP, ZnNKAP and ZnAKAP $\left.\left(2-5 \times 10^{-3} \mathrm{M} \text { in } 0.8 \mathrm{ml} \mathrm{CDCl}\right)_{3}\right)$ were titrated with a solution of the substrate $(2-5 \mathrm{M})$ dissolved in $\mathrm{CDCl}_{3}$ or methanol- $\mathrm{d}_{4}$. The downfield shifts of the naphthyl and anthryl methylene protons linked to the imide were monitored as a function of substrate concentration. Addition was continued until up to $10-15$ equivalents of the substrate had been added. The resultant titration curve was analysed by nonlinear regression methods (Wilcox and Cowart, 1986).

B. UV-Vis method. A similar protocol to A was followed. The increase in absorbance of the Soret peak of the molecular complex and the decrease of the receptor Soret peak were monitored upon the addition of substrate molecules.

C. DSC method. DSC measurements were carried out for the $\mathrm{NKAP}-\mathrm{H}_{2} \mathrm{O}$ crystal under $\mathrm{N}_{2}$ with heating rate at $5{ }^{\circ} \mathrm{C} / \mathrm{min}$.

\section{Crystal Structure Determination}

Data collection was performed on a Nonius diffractometer at room temperature using graphite-monochromated $\mathrm{Cu} \mathrm{K \alpha}$ radiation. The crystals used for analysis were of approximate dimensions $0.30 \times 0.35 \times 0.40 \mathrm{~mm}$ for NKAP and $0.40 \times 0.40 \times 0.70 \mathrm{~mm}$ for ZnNKAP. The unit cell parameters were determined by a least-squares fit of 25 machine-centered reflections having $2 \theta$ values in the ranges of 39.6-44.4 for NKAP and $20.10-27.12^{\circ}$ for ZnNKAP. The intensity data were reduced and corrected for Lorentz and polarization factors using the applied programs. Semiempirical absorption corrections were applied. The crystal structures were solved by direct methods using the NRCVAX program package. All non-hydrogen atoms were refined anisotropically. The hydrogen atoms of the carboxylic group and methanol were located from the difference map and refined positionally. All other hydrogen atoms were calculated with fixed isotropic thermal parameters. The highest difference Fourier peak was 0.31 and 0.35 e $\AA^{-3}$ for NKAP and ZnNKAP, respectively. For NKAP, the final $R$ is 0.047 and $R_{\mathrm{w}}$ is 0.044 ; and for ZnNKAP, $R$ and $R_{\mathrm{w}}$ are 0.040 and 0.042 , respectively. The crystal structure data are available as Supplementary Material which includes crystallographic data, all refined and calculated atomic coordinates and Beq values, and bond distances and angles for $\mathrm{ZnNKAP}$.

Supplementary material. Crystal structure data (5 pages) available from the author.

\section{Acknowledgements}

This work was supported in part by the NIH. We thank Dr G. M. Aviles for her efforts in the initial synthesis of Kemp's isomer porphyrin.

\section{References}

Albert, A. (1968). Heterocyclic Chemistry. 2nd edition, Oxford University Press, New York, pp. 441.

Bonar-Law, R. P. and Sanders, J. K. M. (1995). Polyol recognition by a steroid-capped porphyrin. Enhancement and modulation of misfit guest binding by added water or methanol. $J$. Am. Chem. Soc. 117, 259-271.

Chang, C. K. and Kondylis, M. P. (1986). Intramolecular hydrogen-bonding affecting dioxygen binding to cobalt(II) porphyrins. J. Chem. Soc. Chem. Commun. 316-318.

Chang, C. K., Liang, Y., Avilés, G. A. and Peng, S.-M. (1995). Conformational control of intramolecular hydrogen bonding in heme models: maximal $\mathrm{Co}^{\prime \prime}-\mathrm{O}_{2}$ binding in a C-clamp porphyrin. J. Am. Chem. Soc. 117, 4191-4192.
Dahlquist, F. W., Longmuir, K. J. and Du Vernet, R. B. (1975). Direct observation of chemical exchange by a selective pulse NMR technique. J. Magn. Reson. 17, 406-410.

Imai, H., Nakagawa, S. and Kyuno, E. (1992). Recognition of axial ligands by a zinc porphyrin host on the basis of nonpolar interligand interaction. J. Am. Chem. Soc. 114, 6719-6723.

Kuroda, Y. and Ogoshi, H. (1994). Molecular recognition of modified porphyrins. Synlett. 319-324.

Liang, Y. and Chang, C. K. (1995). Inclusion complex and substrate recognition by C-clamp porphyrins containing Kemp's triacid. Tetrahedron Lett. 36, 3817-3820.

Lindsey, J. S., Kearney, P. C., Duff, R. J., Tjivikua, P. T. and Rebek, 
J., Jr. (1988). Molecular recognition: multipoint contacts with new sizes and shapes. J. Am. Chem. Soc. 110, 6576-6577.

Mizutani, T., Ema, T., Tomita, T., Kuroda, Y. and Ogoshi, H. (1994). Design and synthesis of a trifunctional chiral porphyrin with $\mathrm{C}^{2}$ symmetry as a chiral recognition host for amino acid esters. J. Am. Cham. Soc. 116, 4240-4250.

Momenteau M. and Reed C. A. (1994). Synthetic heme dioxygen complexes. Chem. Rev. 94, 659-698.

Nagy, P., Durant, G. J. and Smith D. A. (1994). Competing intraand intermolecular hydrogen bonds for organic solutes in aqueous solution. In: Modeling the Hydrogen Bond. ed. D. A. Smith. American Chemical Society, Washington DC, pp. 60-79.

Õki, M. (1985). Methods in Stereochemical Analysis, Vol. 4: Applications of Dynamic NMR Spectroscopy to Organic Chemistry. VCH Publishers, Deerfield Beach pp. 1-12.

Rebek, J., Jr. (1987). Model studies in molecular recognition. Science 235, 1478-1484.

Rebek, J., Jr. (1990). Molecular recognition with model systems.
Angew. Chem. Int. Ed. Engl. 29, 245-255.

Rebek, J., Jr., Marshall, L., Wolak, R., Parris, K., Kolloran, M., Askew, B., Nemeth, D. and Islam, N. (1985). Convergent functional groups: synthetic and structural studies. J. Am. Chem. Soc. 107, 7476-7481.

Sandström, J. (1982). Dynamic NMR Spectroscopy. Academic Press, New York, pp 97.

Schneider, H. J. and Durr, H. (Eds) (1991). Host-Guest Molecular Interactions: From Chemistry to Biology. Wiley, Chichester.

Slobodkin, G., Fan, E. and Hamilton, A. D. (1992). Molecular recognition: porphyrin-containing receptors as analogs of barbiturate-induced cytochrome p. 450 . New J. Chem. 16, 643-645.

Staverman, A. J. (1941). The miscibility of water and alkylhalides. Recl. Trav. Chim., 60, 836-841.

Wilcox, C. S. and Cowart, M. D. (1986). New approaches to synthetic receptors. Synthesis and host properties of a water soluble macrocyclic analog of Trögers base. Tetrahedron Lett. 27, 5563-5566. 